\title{
Synthesis of a Tritiated LPS Inhibitor Derived from 3-Deoxy-D-manno-2-octulosonic Acid (KDO). A Cautionary Note Regarding Amide Synthesis from Azides via Phosphine Imines
}

\author{
Christer Sahlberg, Anita M. Jansson and Alf Claesson*
}

Research and Development Laboratories, Astra Alab, S-151 85 Södertälje, Sweden

\begin{abstract}
Sahlberg, C., Jansson, A. M. and Claesson, A., 1988. Synthesis of a Tritiated LPS Inhibitor Derived from 3-Deoxy-D-manno-2-octulosonic Acid (KDO). A Cautionary Note Regarding Amide Synthesis from Azides via Phosphine Imines. Acta Chem. Scand., Ser. B 42: 556-562.

The new antibacterial agent 8-(L-alanyl-L-alanylamino)-2,6-anhydro-3,8-dideoxyD-glycero-D-talo-octonic acid (2a) has been obtained tritiated in the 8-position by a sequence of reactions starting from benzyl 2,6-anhydro-4,5,7-tri- $O$-benzyl-3deoxy-D-glycero-D-talo-octonate. The latter compound was oxidized to the aldehyde which was treated with $\mathrm{NaB}\left[{ }^{3} \mathrm{H}_{4}\right]$ to afford the starting alcohol labelled with tritium. This was converted into the azide which was reduced to the amine by treatment with triphenylphosphine in benzyl alcohol. Coupling of the amine with Cbz-L-Ala-L-Ala and deprotection gave the labelled peptide (2b).

Attempts to form an amide bond directly from the azide by treatment with Cbz-L-Ala and triphenylphosphine according to Horner-Gross give only the corresponding ester. Closer examination of this synthetic method for amides using two model azides has revealed that esters are formed as by-products in both cases. The amount of ester formed is clearly related to the structure of the azide.
\end{abstract}

It has recently been reported from these and other laboratories that dipeptides linked to the amino terminus of compound 1 impart interesting antibacterial properties to the derived products, e.g. compound $2 .{ }^{1-3}$ The amino acid (1) is the 8 -amino-2,8-dideoxy analogue of 3-deoxy- $\beta$-Dmanno-2-octulopyranosonate $(\beta-\mathrm{KDO})$ and is a potent inhibitor of CMP-KDO synthetase which is a cytoplasmic enzyme taking part in the incorporation of KDO into the lipopolysaccharide of Gram-negative bacteria. ${ }^{2-4}$ The inhibitor is, however, efficiently excluded from contact with the target enzyme by the cytoplasmic membrane unless it is incorporated into compounds such as 2 which are actively transported by bacterial peptide permeases and subsequently hydrolysed by peptidases.

The di-Ala derivative (2a) was among the first

\footnotetext{
* To whom correspondence should be addressed.
}

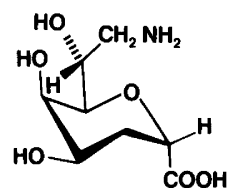

1

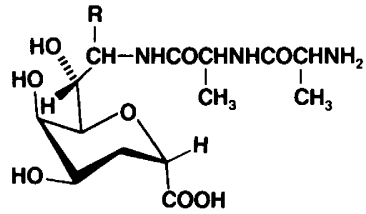

2a $\quad R=H$

2b $R={ }^{3} H$ compounds of this novel class to be synthesized ${ }^{1,2}$ and it has become the subject of more detailed studies regarding uptake/hydrolysis in bacteria. In order to facilitate such studies, it was essential to have this compound in a radioactively labelled form. We report here a synthesis of compound 2 tritiated in the 8-position of the inhibitor part (2b).

Initially, we considered, as a key step, the use of the Horner-Gross reaction ${ }^{5}$ of a suitably labelled derivative to give, after deprotection the 


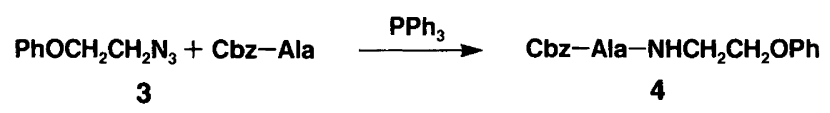

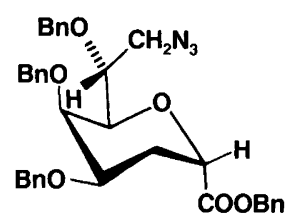

$5 a$

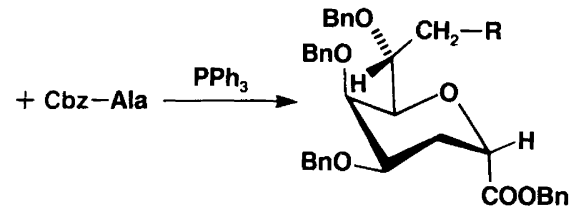

$6 \mathrm{R} \quad 6 \mathrm{R}=\mathrm{Cbz}-\mathrm{Ala}-\mathrm{NH}-$

$7 R=\mathrm{Cbz}-\mathrm{Ala}-\mathrm{O}-$ peptide 2 [see eqns. (1) and (2)]. In the present paper we report that an exploratory experiment according to eqn. (2) aimed at optimization of the reaction conditions unexpectedly gave the ester 7 as the major product rather than the amide. This amide synthesis has recently been described as being novel ${ }^{6}$ and useful in peptide synthesis, ${ }^{7}$ but the formation of other products was not mentioned. We have studied a number of other reactions of this class [eqn. (1) and Table 1] and found that ester formation is a frequently occurring side reaction even though it usually takes place to a limited extent.

\section{Results and discussion}

In order to explore the potential of the HornerGross reaction ${ }^{5}$ in the synthesis of compound $\mathbf{2 b}$, we first studied the reaction depicted in eqn. (1) under varions conditions. Using a rather large excess of benzyloxycarbonylalanine it was possible to increase the yield of amide to $50 \%$ compared with the $30 \%$ yield of $N$-phenylbenzamide reported by Horner and Gross ${ }^{5}$ from a single experiment. In these first experiments we did not bother to characterize minor by-products and hence did not observe the ester product. Therefore the route encompassing the reaction of the azide 5b with $\mathrm{Cbz}$-alanylalanine to give amide 11 (Scheme 1) was considered quite feasible. This step was immediately attempted using benzyloxycarbonylalanine and the azide $5 \mathbf{a}^{4}$ [eqn. (2)] under the conditions used in the model reaction; a major product was indeed isolated in a yield of $36 \%$. NMR and in particular mass spectrometry indicated, however, that the product could not have the expected structure but must be the ester (7) shown in eqn. (2). That no amide 6 was formed from the azide was corroborated by its independent synthesis from the non-labelled amine (10) (Scheme 1). For the planned synthesis of compound 11 we therefore had to resort to a circumventional route that involved reduction of the azide to the amine followed by conventional peptide synthesis (Scheme 1).

Synthesis of the tritium-labelled peptide. We chose to introduce the label at the 8-position of the sugar since we had access to the fully benzylprotected alcohol analogue of compound 1, i.e. compound 8a in the Scheme. ${ }^{4}$ With this compound in hand we could devise a synthetic strategy which was based on the oxidation of 8a followed by reduction of the resulting aldehyde with tritiated sodium borohydride. These reactions should give tritium-labelled 8a which could then be transformed into the desired final product via an azide. The soundness of this strategy was verified by runs using unlabelled material. Compound 8a was thus oxidized by the method described by Swern. ${ }^{8}$ The crude aldehyde thus obtained in a yield of about $70 \%$ could then be readily reduced with $\mathrm{NaBH}_{4}$ to give compound 8a. Application of this methodology using 9.25 $\mathrm{GBq}(250 \mathrm{mCi})$ of $\mathrm{NaB}\left[{ }^{3} \mathrm{H}_{4}\right]$ gave, after silica-gel chromatography, compound $\mathbf{8 b}$ in a yield of about $68 \%$ and with a radiochemical purity of $>95 \%$.

This compound was then converted into the azide $\mathbf{5 b}$ according to the conditions described in the Scheme 1. The azide was reduced by $\mathrm{Ph}_{3} \mathrm{P}$ and benzyl alcohol in THF to give the amine 10. The overall yield from compound $8 \mathrm{a}$ was $20 \%$. Compound 10 was treated with benzyloxycarbonyl-L-alanyl-L-alanine in the presence of dicyclohexylcarbodiimide (DCC), $\mathrm{Et}_{3} \mathrm{~N}$ and 1-hydroxy- 


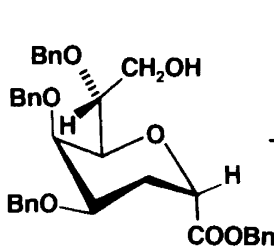

$8 \mathrm{a}$

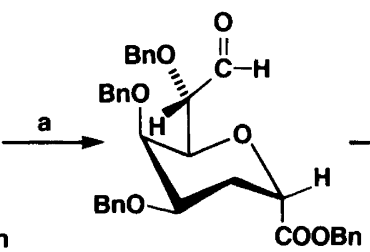

9

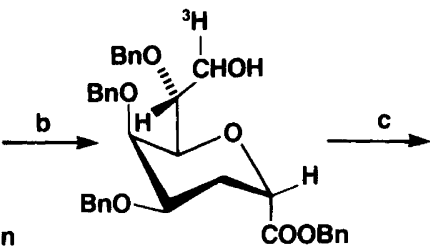

$8 b$

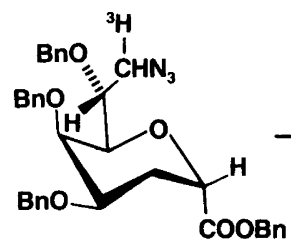

$5 \mathbf{b}$

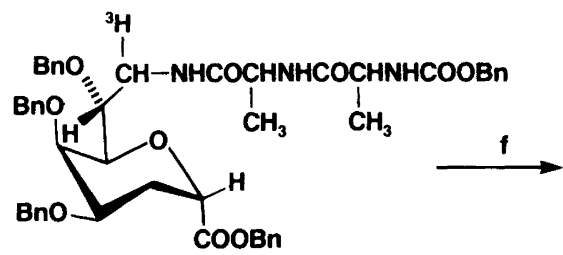

11

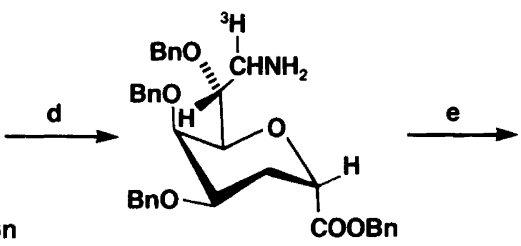

10

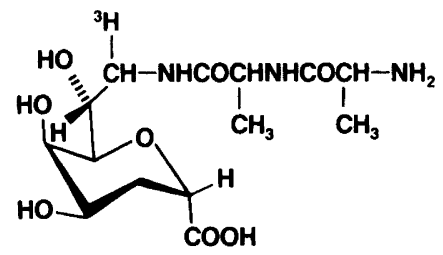

$2 b$

Scheme 1. Reagents: $\mathrm{a}=(\mathrm{COCl})_{2}, \mathrm{Me}_{2} \mathrm{SO}, \mathrm{Et}_{3} \mathrm{~N} ; \mathrm{b}=\mathrm{NaB}\left[{ }^{3} \mathrm{H}_{4}\right] ; \mathrm{c}=\mathrm{LiN}_{3}, \mathrm{CBr}_{4}, \mathrm{PPh}_{3} ; \mathrm{d}=\mathrm{PPh}_{3}$, $\mathrm{PhCH}_{2} \mathrm{OH} ; \mathrm{e}=\mathrm{Cbz}-\mathrm{L}-\mathrm{Ala}-\mathrm{L}-\mathrm{Ala}, \mathrm{DCC}, \mathrm{HOBT}, \mathrm{Et}_{3} \mathrm{~N} ; \mathrm{f}=\mathrm{H}_{2}, \mathrm{Pd} / \mathrm{C} . \mathrm{Bn}=$ benzyl.

benzotriazole to give the protected dipeptide (11) in high yield. Deprotection using catalytic hydrogenation under pressure afforded the desired compound in an overall radiochemical yield of $4 \%$. The specific activity was $5.85 \mathrm{GBq} \mathrm{mmol}^{-1}$. This compound has been used as an essential tool in the elucidation of the biochemical behaviour of this type of novel antibacterial agent.

Further studies on ester formation. Because of the abnormal results obtained according to eqn. 2, where no amide 6 could be isolated, the earlier model reaction shown in eqn. (1) was re-examined in order to find an ester product. A small amount of this compound could indeed be isolated (entry 2, Table 1). Running this reaction in toluene at a higher temperature afforded the same amount of ester. In order to study further the factors that might govern the relative amounts of ester and amide formation we used another azide (entries 4-6) which more closely resembles compound 5a. Use of the varying conditions shown in the Table 1 consistently afforded larger amounts of ester relative to amide than was the case with the azide 3 . The total yield of ester plus amide never exceeded ca. $50 \%$ which contrasts with the higher yields of amides reported for simpler compounds. ${ }^{6}$ Our results are, however, in accordance with the rather low and varying yields reported for peptide formation from azides derived from amino acids. ${ }^{\text {? }}$

In contrast with other workers reporting this amide synthesis we used dichloromethane as a solvent instead of refluxing toluene. This change does not, however, provide a satisfactory explanation as to the diverging results since we were also able to isolate an ester product from experiments run in hot toluene (entries 3 and 5). Therefore the possibility cannot be excluded that undetected ester products were in fact also formed 
in the experiments reported earlier ${ }^{6,7}$ The generally good yields of amides reported ${ }^{6}$ and the result obtained with the less complicated reactant used in eqn. (1) suggests, however, that the main reason for the anomalous ester formation lies in the particular arrangement of oxygens and carbons in azides such as 5 and the one used in entries 4-6. We do not wish to speculate further on the factors that underlie the unexpected change in direction that the present reaction may take for certain substrates. Clearly, however, the results presented here warrant due caution in planning the synthesis of amides directly from azides and carboxylic acids.

\section{Experimental}

${ }^{1} \mathrm{H}$ and ${ }^{13} \mathrm{C}$ NMR spectra were recorded at 199.5 $\mathrm{MHz}$ and $50.1 \mathrm{MHz}$, respectively, on a JEOL FX 200 spectrometer using tetramethylsilane (TMS) as an internal standard. IR spectra were recorded with a Perkin-Elmer 298 spectrometer and the chemical-ionization mass spectrum was obtained using a LKB 2091 mass spectrometer. Elemental analyses were carried out at the Department of Analytical Chemistry, University of Lund. Radiochemical purity was determined by scanning $\mathrm{SiO}_{2}$ plates (Merck silica gel $60 ; 0.2 \mathrm{~mm}$ ), using a Berthold LB 283 TLC linear analyser. Radioactivity was measured in a Packard Tri-Carb 460 C liquid scintillation spectrometer. $\mathrm{NaB}\left[{ }^{3} \mathrm{H}_{4}\right]$ $\left(425.5 \mathrm{GBq} \mathrm{mmol}^{-1}\right)$ was purchased from Amersham, U.K. Preparative column chromatography was performed on Merck silica gel $60(230-400$ mesh) or on Merck cellulose microcrystalline.

General procedures for the reactions in Table 1. Triphenylphosphine and a carboxylic acid were added to a solution of the azide under dry and oxygen-free conditions. Solvents, amounts, temperature and reaction times are given in Table 1. The reaction mixture was concentrated and purification was carried out by flash chromatography on silica gel with appropriate mixtures of ethyl acetate and hexane. The structures were determined by ${ }^{1} \mathrm{H}$ and ${ }^{13} \mathrm{C}$ NMR spectroscopy.

Benzyl 2,6-anhydro-4,5,7-tri-O-benzyl-8-(benzyloxycarbonyl-L-alanylamino)-3,8-dideoxy-D-

glycero-D-talo-octonate (6). Compound 6 was prepared from the azide $5 \mathrm{a}$ via the amine and with $\mathrm{N}$-Cbz-alanine according to the same proce- dures as described for compounds 10 and 11 (see below). The yield was $45 \%(0.2 \mathrm{mmol}$ scale $)$ after the product had been purified on silica gel with EtOAc-hexane (1:2) and crystallized from diethyl ether-light petroleum. $R_{\mathrm{f}} 0.14$ (EtOAchexane 1:2). Anal. $\mathrm{C}_{47} \mathrm{H}_{50} \mathrm{~N}_{2} \mathrm{O}_{9}: \mathrm{C}, \mathrm{H}, \mathrm{N} .{ }^{13} \mathrm{C}$ NMR $\left(\mathrm{CDCl}_{3}\right): \delta 172.8,172.5,155.6(\mathrm{C}=\mathrm{O})$, 138.7, 138.1, 137.8, 136.8, 135.1 (C aromatic). 127.3-128.8 (CH aromatic), 76.2, 74.9, 74.8, 72.8, 72.0 (C-2, -4, -5, -6, -7), 74.3, 70.8, 70.5, 67.6, $66.6\left(5 \mathrm{CH}_{2} \mathrm{Ph}\right), 50.8$ (CH Ala), $36.6(\mathrm{C}-8)$, 27.2 (C-3), $20.0\left(\mathrm{CH}_{3}\right.$ Ala). IR $\left(\mathrm{CHCl}_{3}\right): 1730$ (benzyl ester and carbamate), $1675 \mathrm{~cm}^{-1}$ (amide).

Benzyl 2,6-anhydro-4,5,7-tri-O-benzyl-8-O-(benzyloxycarbonyl-L-alanyl-3-deoxy-D-glycero-D-

talo-octonate (7). According to the general conditions described above, $70 \mathrm{mg}(36 \%)$ of compound ( 7 was obtained after purification on silica gel with EtOAc-hexane (1:3) from $150 \mathrm{mg}$ of the azide $5 \mathrm{a} .{ }^{4} R_{\mathrm{f}} 0.45$ [EtOAc-hexane (1:2)]. CI-MS: $788\left(4 \%,[\mathrm{M}+1]^{+}\right) .{ }^{13} \mathrm{C} \mathrm{NMR}\left(\mathrm{CDCl}_{3}\right): \delta 172.4$, $171.2,155.6(\mathrm{C}=\mathrm{O}), 138.9,138.2,137.9,135.6$ (C aromatic), 127.3-128.6 ( $\mathrm{CH}$ aromatic), 76.4, 75.4, 73.7, 72.6, 72.5 (C-2, -4, -5, -6, -7), 74.2, $71.9,70.5,66.8,66.7\left(5 \mathrm{CH}_{2} \mathrm{Ph}\right), 63.1$ (C-8), 50.2 (CH Ala), 27.2 (C-3), $19.1\left(\mathrm{CH}_{3}\right.$ Ala). IR $\left(\mathrm{CHCl}_{3}\right): 1720 \mathrm{~cm}^{-1}$ (broad band, esters and carbamate).

Benzyl 2,6-anhydro-4,5,7-tri-O-benzyl-3-deoxy$\left[8-{ }^{3} \mathrm{H}\right]$-D-glycero-D-talo-octonate $8 \mathbf{b}$. To a solution of oxalyl chloride $(18 \mu \mathrm{l}, 0.206 \mathrm{mmol})$ in $\mathrm{CH}_{2} \mathrm{Cl}_{2}(2 \mathrm{ml})$ at $-60^{\circ} \mathrm{C}$ and under nitrogen, was added $\mathrm{Me}_{2} \mathrm{SO}(29 \mu \mathrm{l} ; 0.411 \mathrm{mmol})$. The reaction mixture was stirred for $15 \mathrm{~min}$ and compound $\mathbf{8 a}^{4}$ ( $80 \mathrm{mg}, 0.137 \mathrm{mmol})$ in $\mathrm{CH}_{2} \mathrm{Cl}_{2}(2 \mathrm{ml})$ was added. The temperature was kept at $-60^{\circ} \mathrm{C}$ and stirring was continued for another $15 \mathrm{~min}$. Triethylamine $(115 \mu \mathrm{l}, 0,822 \mathrm{mmol})$ was slowly added and the cooling bath was then removed. The reaction mixture was stirred for $60 \mathrm{~min}$ whereupon the crude reaction mixture was partitioned between EtOAc $(3 \mathrm{ml})$ and brine $(3 \mathrm{ml})$. The organic phase was separated and the aqueous phase extracted with EtOAc $(2 \times 3 \mathrm{ml})$. The combined extracts were dried $\left(\mathrm{Na}_{2} \mathrm{SO}_{4}\right)$ and evaporation of the solvent gave $79 \mathrm{mg}$ of crude and uncharacterized 9. It was later found that the aldehyde 9 could be purified on a silica gel column using EtOAc-hexane $(1: 3 \mathrm{v} / \mathrm{v})$ as the eluent. The yield 


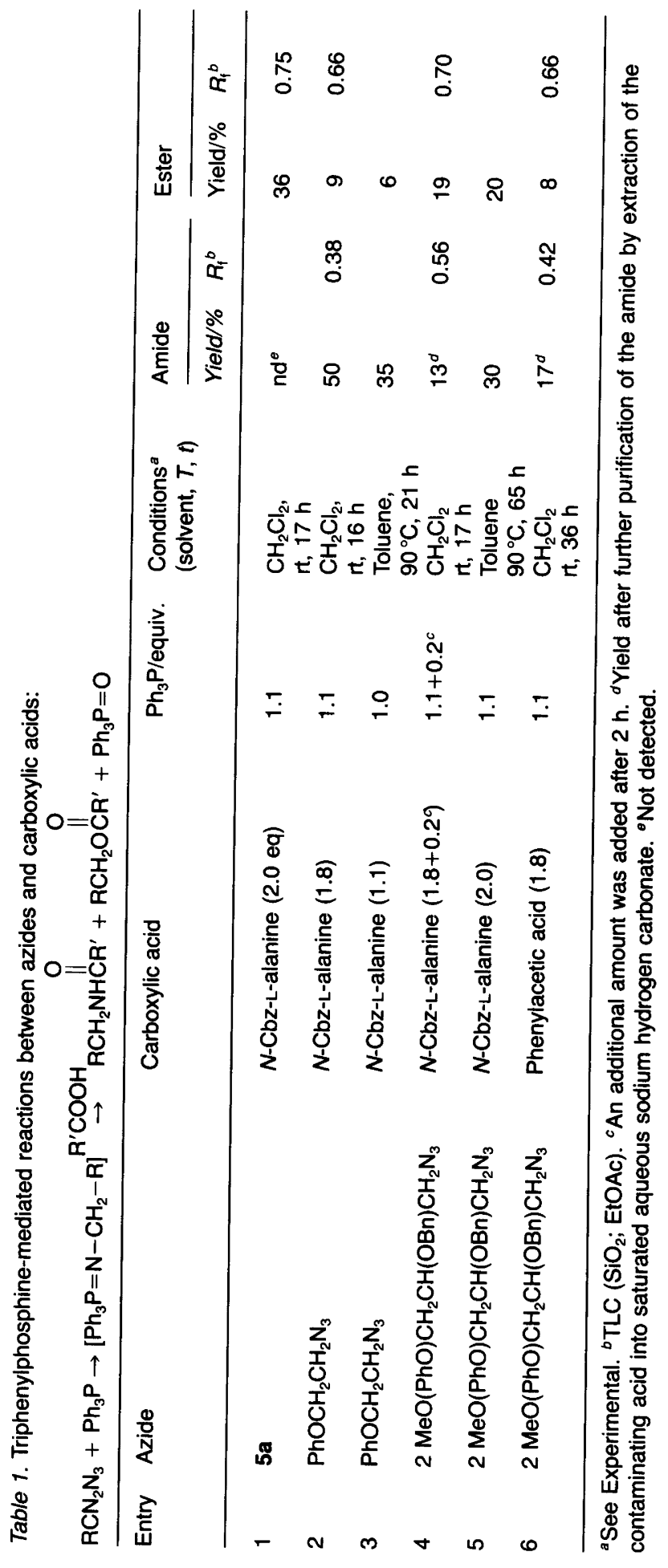


obtained on a $3 \mathrm{mmol}$ scale was $80 \%$. Anal. $\mathrm{C}_{36} \mathrm{H}_{36} \mathrm{O}_{7}: \mathrm{C}, \mathrm{H} .{ }^{13} \mathrm{C}$ NMR $\left(\mathrm{CDCl}_{3}\right): \delta 200.4$ (CHO), 170.9 (C-1), 138.7, 138.1, 137.2, 135.4 (C aromatic), 127.3-128.6 (CH aromatic), 80.4, 75.5, 74.6, 72.9, 72.4 (C-2, -4, -5, -6, -7), 72.4, $72.5,70.4,66.8\left(4 \mathrm{CH}_{2} \mathrm{Ph}\right), 27.2(\mathrm{C}-3)$.

Crude 9 was dissolved in $\mathrm{EtOH}(4 \mathrm{ml})$ and 9.25 $\mathrm{GBq}(0.0217 \mathrm{mmol})$ of $\mathrm{NaB}\left[{ }^{3} \mathrm{H}_{4}\right]$ was added. The reaction mixture was stirred for $45 \mathrm{~min}$ whereupon $\mathrm{NaBH}_{4}(2.5 \mathrm{mg})$ was added. Stirring was continued for further $15 \mathrm{~h}$. After the addition of $\mathrm{CH}_{3} \mathrm{COOH}$ (4 drops) followed by saturated $\mathrm{NaHCO}_{3}$ solution $(4 \mathrm{ml})$, the reaction mixture was extracted with $\mathrm{CH}_{2} \mathrm{Cl}_{2}(3 \times 4 \mathrm{ml})$. The combined extracts were dried $\left(\mathrm{Na}_{2} \mathrm{SO}_{4}\right)$ and evaporation of the solvent gave crude $\mathbf{8 b}$. Purification of this on silica gel using EtOAc-hexane $(2: 3 \mathrm{v} / \mathrm{v})$ as the eluent gave, after the addition of $23 \mathrm{mg}$ of compound $8 \mathrm{a}, 70 \mathrm{mg}$ of the title compound. TLC $\left[\mathrm{SiO}_{2} ;\right.$ EtOAc-hexane $\left.(2: 3 \mathrm{v} / \mathrm{v})\right]$ indicated that the radiochemical purity of $\mathbf{8 b}$ was $>95 \%$.

Benzyl 2,6-anhydro-8-azido-4,5,7-tri-O-benzyl3,8-dideoxy-D-glycero-D-talo-octonate (5b). To a solution of compound $(8 \mathrm{~b})(70 \mathrm{mg}, 0.12 \mathrm{mmol})$ was added $\mathrm{CBr}_{4}(66 \mathrm{mg}, 0.20 \mathrm{mmol})$ and $\mathrm{LiN}_{3}(34$ $\mathrm{mg}, 0.70 \mathrm{mmol})$ in DMF $(1 \mathrm{ml})$, at $0^{\circ} \mathrm{C}$ and under nitrogen, followed by $\mathrm{PPh}_{3}(52 \mathrm{mg} ; 0.20 \mathrm{mmol})$. The reaction mixture was allowed to reach room temperature and stirred for $48 \mathrm{~h}$. The reaction mixture was lyophilized and the residue was purified on silica gel using EtOAc-hexane $(1: 2 \mathrm{v} / \mathrm{v})$ as the eluent. The appropriate fractions were collected and evaporation of the solvent gave $69 \mathrm{mg}$ of compound (5b) (with some remaining $\mathrm{Ph}_{3} \mathrm{P}$ ). The radiochemical purity was $>98 \%$ according to $\mathrm{TLC}\left[\mathrm{SiO}_{2} ; \mathrm{EtOAc}-\right.$ hexane $\left.(1: 2 \mathrm{v} / \mathrm{v})\right]$.

Benzyl 8-amino-2,6-anhydro-4,5,7-tri-O-benzyl3,8-dideoxy-[8- $\left.{ }^{3} \mathrm{H}\right]$-D-glycero-D-talo-octonate

(10). To a solution of compound $5 \mathrm{~b}(69 \mathrm{mg})$ in benzyl alcohol $(1.0 \mathrm{ml})$ was added a solution of $\mathrm{Ph}_{3} \mathrm{P}(210 \mathrm{mg}, 0.80 \mathrm{mmol})$ in THF $(1.0 \mathrm{ml})$ and benzyl alcohol $(1.0 \mathrm{ml})$. The reaction mixture was stirred under nitrogen at $20^{\circ} \mathrm{C}$ for $24 \mathrm{~h}$. THF was then removed with a stream of nitrogen gas and the residue was purified on a silica-gel column, which was first eluted with $\mathrm{CHCl}_{3}$ followed by $\mathrm{CHCl}_{3}-\mathrm{CH}_{3} \mathrm{OH}(9: 1 \mathrm{v} / \mathrm{v})$. This gave $21 \mathrm{mg}$ of the title compound. Yield: $8 \mathrm{a} \rightarrow$ 10: $20 \%$. The radiochemical purity was $>99 \%$ as determined by
TLC $\left[\mathrm{SiO}_{2} ; \mathrm{CHCl}_{3}-\mathrm{PhCH}_{3}-\mathrm{CH}_{3} \mathrm{OH}(5: 2: 1 \mathrm{v} / \mathrm{v})\right]$. The non-labelled compound has been described. ${ }^{9}$

Benzyl 2,6-anhydro-4,5,7-tri-O-benzyl-8-(benzyloxycarbonyl-L-alanylamino)-3,8-dideoxy- $\left[8-{ }^{3} \mathrm{H}\right]$ D-glycero-D-talo-octonate (11). To a solution of compound 10 ( $21 \mathrm{mg}, 0.036 \mathrm{mmol})$ in $\mathrm{CH}_{2} \mathrm{Cl}_{2}(2.0$ $\mathrm{ml}$ ) was added Cbz-L-Ala-L-Ala (21.2 mg, 0.0722 mmol), triethylamine $(10 \mu \mathrm{l}, 0.072 \mathrm{mmol})$ and 1-hydroxybenzotriazole $(5.4 \mathrm{mg}, 0.040 \mathrm{mmol})$. The reaction mixture was cooled to $0^{\circ} \mathrm{C}$ and 8.2 $\mathrm{mg}(0.040 \mathrm{mmol})$ of DCC was added. The reaction mixture was allowed to reach room temperature and stirred for 5 days. The crude 11 was then purified on a silica-gel column. The eluent was initially EtOAc-hexane (1:2 v/v) followed by EtOAc-hexane $(2: 1 \mathrm{v} / \mathrm{v})$. The fractions that contained compound 11 were collected. Evaporation of the solvent gave $35 \mathrm{mg}$ of the title compound (with some DCC remaining). The radiochemical purity was $>97 \%$ as determined by $\mathrm{TLC}\left[\mathrm{SiO}_{2}\right.$; EtOAc-hexane $(1: 1 \mathrm{v} / \mathrm{v})]$. The non-labelled compound has been described. ${ }^{9}$

8-(L-Alanyl-L-alanylamino-2,6-anhydro-3,8-dideoxy-[8- $\left.{ }^{3} \mathrm{H}\right]$-D-glycero-D-talo-octonate (2b). A suspension of $11(35 \mathrm{mg})$ and $10 \% \mathrm{Pd} / \mathrm{C}(75 \mathrm{mg})$ in THF ( $3 \mathrm{ml})$ and $\mathrm{H}_{2} \mathrm{O}(1 \mathrm{ml})$ was hydrogenated at $20^{\circ} \mathrm{C}$ and $4 \mathrm{~atm}$, using a Parr apparatus, for $5 \mathrm{~h}$. The reaction mixture was filtered (Millipore filter) and the filtrate was freeze dried to give 11.4 $\mathrm{mg}$ of crude $\mathbf{2 b}$. This was purified on a Cellulose column eluting first with 1-propanol followed by 1-propanol- $\left.\mathrm{H}_{2} \mathrm{O}(3: 2 \mathrm{v} / \mathrm{v})\right]$. The appropriate fractions were collected and evaporation together with $10 \mathrm{mg}$ of $2 \mathrm{a}$ gave $22 \mathrm{mg}$ of the title compound. The yield for the reaction $\mathbf{1 0}$ to $\mathbf{2 b}$ was $95 \%$. The radiochemical purity was $>95.6 \%$ as determined by TLC $\left[\mathrm{SiO}_{2} ; 1\right.$-propanol- $\mathrm{H}_{2} \mathrm{O}(3: 2$ $\mathrm{v} / \mathrm{v})$. The specific activity was $5.85 \mathrm{GBq} \mathrm{mmol}^{-1}$ (154 $\mathrm{mCi} \mathrm{mmol}^{-1}$ ) as measured by weighing.

Acknowledgement. We thank Dr. B. G. Pring for comments on the manuscript.

\section{References}

1. Claesson, A., Jansson, A. M., Pring, B. G., Hammond, S. M. and Ekström, B. J. Med. Chem. 30 (1987) 2309. 
2. Hammond, S. M., Claesson, A., Jansson, A. M., Larsson, L. G., Pring, B. G., Town, C. and Ekström, B. Nature (London) 327 (1987) 730.

3. Goldman, R., Kohlbrenner, W., Lartey, P. and Pernet, A. Nature (London) 329 (1987) 162.

4. Pring, B. G., Jansson, A. M., Persson, K., Andersson, A., Gagner-Milchert, I., Gustafsson, K. and Claesson, A. J. Med. Chem. Submitted.

5. Horner, L. and Gross, A. Justus Liebigs Ann. Chem. 591 (1955) 117.

6. Garcia, J., Urpi, F. and Vilarrasa, J. Tetrahedron Lett. 25 (1984) 4841.
7. Zaloom, J., Calandra, M. and Roberts, D.C. J. Org. Chem. 50 (1985) 2601.

8. Omura, K. and Swern, D. Tetrahedron 34 (1978) 1651.

9. Claesson, A., Hammond, S. H., Jansson, A. M. and Pring, B. G. International Patent Application No. PCT/SE 86/00574. (1986).

Received March 2, 1988. 